\title{
TRAUMA BONDING: CONCEPTS, CAUSES AND MECHANISMS IN INTIMATE RELATIONSHIPS
}

\section{THEORETICAL TEST}

FONSECA, Nicole de Queiroz Lima ${ }^{1}$, OLIVEIRA, Bruno Quintino de ${ }^{2}$

FONSECA, Nicole de Queiroz Lima. OLIVEIRA, Bruno Quintino de. Trauma Bonding: concepts, causes and mechanisms in intimate relationships. Revista Científica Multidisciplinar Núcleo do Conhecimento. Year. 06, Ed. 11, Vol. 06, pp. 6078. November 2021. ISSN: 2448-0959, Access Link: https://www.nucleodoconhecimento.com.br/psychology/intimate-relationships, DOI: 10.32749/nucleodoconhecimento.com.br/psychology/intimate-relationships
"Não te quero senão porque te quero
e de querer-te a não querer-te chego
e de esperar-te quando não te espero
passa meu coração do frio ao fogo.
Quero-te apenas porque a ti eu quero,
a ti odeio sem fim e, odiando-te, te suplico,
e a medida do meu amor viajante
é não ver-te e amar-te como um ego...”.
(PABLO NERUDA - SONETO LXVI).

\section{ABSTRACT}

When, after a violent incident, strong emotional bonds are established in order to connect two people, there is the installation of a trauma called by the literature as

\footnotetext{
${ }^{1}$ Psychology student. ORCID: 0000-0003-1739-9532

2 PhD student in Psychoanalytic Theory - UFRJ, Master in Clinical Psychology - PUC RJ, Specialist in Mental Health - HU/UFJF, Degree in Psychology - UFF. ORCID: 0000-0002-7956-7899

RC: 101110

Available in: https://www.nucleodoconhecimento.com.br/psychology/intimaterelationships
} 
trauma bonding. It is an emotional dependence between two people, in a relationship characterized by periods of abuse, violence and power imbalance, with bonds of intense connection, cognitive distortion and behavioral strategies of both individuals that paradoxically strengthen and maintain the bond, which is reflected in the vicious cycle of violence. However, there is a lack of literature and scientific research on the subject in Brazil, which highlights the need for a refined and in-depth study, since the causes and effects of trauma bonding are still not exactly clear, which makes the understanding and treatment of individuals, as well as their recovery, a slow and painful process. Thus, this research is guided by the question: what is trauma bonding and what are its mechanisms? Thus, it was defined as the general objective to analyze trauma bonding in loving relationships, in order to give birth to the neuropsychobiological processes of trauma generated in intimate relationships and to investigate the reasons why victims remain in pathological relationships, we will also address the functioning of Stockholm Syndrome and posttraumatic stress in victims of abuse in loving relationships as factors that generate trauma bonding. For contextualization, problematization and validation of the theoretical framework used in the research undertaken, the methodology used was the literature review or bibliographic review, from the reading, selection and analysis of texts of different genres, such as records, reviews and scientific articles related to the subject and which were published in journals and newspapers in the area. It was concluded that several emotional and neuropsychobiological factors are the cause for trauma bonding to be established within a relationship.

Keywords: Trauma, trauma bonding, Post-traumatic stress, Stockholm Syndrome, Violence in intimate relationships.

\section{INTRODUCTION}

This research aims to analyze trauma bonding in intimate relationships in which there is a certain pattern of behavior based on abuse by one of the partners. Much is said of psychological and sexual abuse within affective relationships and the effects they cause, however, the main objectives of this research are of two distinct and

RC: 101110

Available in: https://www.nucleodoconhecimento.com.br/psychology/intimaterelationships 
interconnected natures: a) to give light to the neuropsychobiological processes of trauma generated in intimate relationships; and b) investigate the reasons why victims remain in pathological relationships.

The lack of literature and scientific research in this area in Brazil brings to light the need for a refined and in-depth study, since the causes and effects of trauma bonding are still not exactly clear, which makes the understanding and treatment of individuals, as well as their recovery, a slow and painful process. Trauma victims need to learn how to create relationships that are not based on fear and abuse of power, even if such abuse of power is perceived as natural and certain (BLOOM, 1999).

In common sense, there is the widespread idea that people who remain in relationships considered abusive do so solely motivated by issues of financial, social dependence, low self-esteem and/or psychological dependence. Although such aspects may be pertinent, studies indicate that trauma bonding is what, in fact, keeps subjects in precarious situations in their loving relationships. In his work "The Betrayal Bond", Carnes (2019) explains that:

Trauma bonds são formas disfuncionais de ligação que ocorrem na presença de perigo, vergonha e abuso. Esses relacionamentos são bem diferentes das ligações que ocorrem naturalmente quando experimentamos um evento traumático com outras pessoas e o resultado geralmente é uma união ou estreitamento de uma ligação como método de sobrevivência. Trauma bonds, por outro lado, acontecem quando nos apegamos à exata pessoa que é a fonte do medo, vergonha e abuso. Este tipo de ligação não facilita a recuperação e resiliência, sabotando tais qualidades em nós, e frequentemente deixam um impacto a longo prazo, geralmente envolvendo sedução e traição[3]. (CARNES, 2019, p. 121).

Traumatic (or trauma) bondings are created when strong emotional bonds are established to connect two people, after an incident in which a person assaults, expresses violent behavior, is abusive, intimidating and threatening. It is an emotional dependence between two people, in a relationship characterized by periods of abuse, violence and imbalance of power. The root of this bond is marked 
by feelings of intense connection, cognitive distortion and behavioral strategies of both individuals that paradoxically strengthen and maintain the bond, which is reflected in the vicious cycle of violence (DEYOUNG; LOWRY, 1992).

From the physiological point of view, it can be said that the human brain, in all its complexity, is triggered during the psychosocial process of trauma bonding generation. Authors such as Van Der Kolk (1989, 1991, 1994, 2001), Simonič and Osewska (2019), Fisher (2010) and Bloom (1999) postulate studies showing evidence that people suffering from frequent or prolonged abuse, as well as childhood trauma, are more likely to engage in traumabonding relationships, due to a reward mechanism of the body, which seeks the repetition of certain sensations generated by the discharge of endorphins after the end of the crisis situation.

Second. Bloom (1999), in his work "Trauma Theory Abbreviated",such a mechanism works similarly to what occurs in organisms of people dependent on narcotic substances:

[...]essas substâncias mágicas chamadas endorfinas são parte do funcionamento normal e corriqueiro, mas elas são especialmente importantes em momentos de estresse. Novamente, se olharmos para a evolução, faz sentido. Endorfinas não apenas acalmam a ansiedade, melhoram nosso humor e diminuem a agressividade, mas também são ótimos analgésicos já que são relacionados com a morfina e a heroína. Portanto, em tempos de estresse, elas propiciam alívio para a dor o suficiente para que não sejamos incapacitados por ferimentos que poderiam nos impedir de escapar do perigo. Se as pessoas são expostas a raros episódios de intenso estresse, elas possuem menos chances de mostrarem quaisquer mudanças em seu sistema bioquímico. O problema reside nas pessoas que são expostas repetidamente a experiências de estresse prolongado. Tais pessoas, geralmente crianças, são expostas a altos níveis de endorfinas frequentemente. Uma hipótese é a de que os indivíduos podem se tornar 'viciados' em suas próprias endorfinas e, como resultado, só se sentem calmas quando estão sob stress, com medo, irritáveis e hiper excitadas quando o estresse é aliviado, bastante similar a pessoas em abstinência de heroína. Isso é chamado de 'vício em trauma'[4]. (BLOOM, 1999, p. 9).

Several hormones generated in the human body are involved in the so-called "trauma addiction" that strengthens or induces the bond with the abuser, such as

RC: 101110

Available in: https://www.nucleodoconhecimento.com.br/psychology/intimaterelationships 
oxytocin - which causes the bonds and affectivity; endogenous opioids, responsible for pleasure, pain, abstinence and dependence; corticotropin release factor, causing abstinence and stress; dopamine - generating craving, desire, search. With so many neurochemical factors in deregulated states, it is extremely difficult for the subject to modulate their emotions and make decisions (BURKETT; YOUNG, 2012).

Other hormones influence the reaction (or lack thereof) in the person in the face of a situation of violence and/or permanence of individuals in an abusive relationship. The perception that punishment is imminent activates two brain mechanisms in the subject: one that inhibits the previous behavior, which supposedly generated the reason for punishment; and the other, which increases the levels of excitement in the face of the violent situation generated. The central nervous system, in this circumstance, activates the triggers for emergencies and generates the behavioral and cognitive responses of the subject, to protect itself from a possible attack (BURKETT; YOUNG, 2012).

Several studies show that serotoninergic antagonists increase aggressiveness in response to stress and hyper-reactivity in response to stimuli, but the suppression of behaviors caused by punishment is reversed by serotonin blockers (VAN DER KOLK; SAPORTA, 1991), which raises the hypothesis that the low in serotonergic levels in victims of trauma and posttraumatic stress is responsible for the continuation of emergency responses to smaller stimuli, even when the cause of trauma is stopped.

Van Der Kolk and Saporta (1991) also explain that the severity of posttraumatic stress cases is related to cortisol levels in the subject's body, which supports the hypothesis that there is a chronic increase in cortisol in individuals affected by posttraumatic stress.

The term "Stockholm Syndrome" was coined in 1973, following the event of a bank robbery in Stockholm, Sweden, where criminals and hostages remained confined for six days (MARTIN, 2005). There are reports that in these six days, the victims have developed empathy, affection and complicity with their kidnappers. Because it was 
understood that it was a link between abuser and victim, such a relationship seemed strange to the most attentive eyes, and the psychiatrist and criminologist Nils Bejerot baptized this phenomenon of Stockholm Syndrome.

Investigating other experiences throughout the history of mental health in the West, it was noticed that this phenomenon was especially common in some religious cults, in relations with possible prisoners of war, in family relationships with cases of children victims of abuse or incest, among other groups. It was also identified that this syndrome is also developed in loving relationships, in which the victim ends up creating a traumatic connection with his abuser (GEORGE, 2015).

According to Graham et al. (1995), there are four precursors of Stockholm Syndrome: a) the life-threatening sensation; b) apparent kindness; c) isolation; and d) the apparent inability to escape the situation.

Stockholm Syndrome, then, is a defense mechanism for the individual to deal with such factors, which may include cognitive distortions and perception of reality (GEORGE, 2015)

Such distortions are also called cognitive dissonances, by Leon Festinger, in his work "A Theory Of Cognitive Dissonance" (1957). For the author, these dissonances exist when there is a conflict or incongruity between distinct beliefs, or when the subject is confronted with information that refutes his previous beliefs. Cognitive dissonance creates an uncomfortable psychological state, which motivates the creation of brain mechanisms in the form of strategies to reduce discomfort.

Applying such a theory to an abusive relationship, the victim ends up creating particular elaborations or even justifications for the behavior of his partner, since his main belief is that he is not being abused. Even in the face of facts and evidence, the victim finds himself unable to refute his cognitive dissonance. In view of the above picture, we can perceive that remaining in an abusive relationship is not a purely psychological or social issue. The identification of the occurrence of trauma in childhood and throughout life is fundamental to understand how neurological patterns

RC: 101110

Available in: https://www.nucleodoconhecimento.com.br/psychology/intimaterelationships 
and traumatic bonds are formed from trauma and remain throughout life (GEORGE, 2015).

Individuals who are subjected to high levels of stress and cortisol since childhood, by family abuse, abandonment, incest, among other violent situations, end up unconsciously searching or being attracted to people who tend to behaviors considered abusive that can provide conflict and the feeling of fear, shame and abuse to which they are accustomed and that their brains need to modulate hormone levels (BLOOM, 1999).

The psychological and organic reactions faced by subjects who, at some point in their lives, decide to leave relationships considered abusive are similar to those that addicts of narcotic substances in abstinence experience, which brings strong indications of the presence of a mechanism that relates human hormonal production with trauma bonding (BLOOM, 1999).

From this exhibition, the relevance of this study is defended, which aims to investigate such dynamics so that individuals hostage to these connections can, in fact, recover effectively from traumas - past and present - and thus prevent the cycle from repeating itself in the future.

The need to deepen the understanding of the concept of trauma bonding for the reception and treatment of individuals, as well as to understand its biopsychosocial functioning and short- and long-term effects, make the research of this theme of clinical, theoretical, social and political importance.

Violence, physical and emotional, in intimate relationships, is a comprehensive and harmful phenomenon that occurs throughout society, without gender differentiation, affecting men, women, intersex people and other gender identities, resulting in various psychological, social and even physical problems.

Understanding the neuropsychological aspects in trauma bonding and "trauma addiction" is a task of paramount importance, because, from such competencies, it 
will be possible to create clinical intervention strategies in these types of cases. As an initial point for the future construction of a clinical protocol, it is understood that physiological stability, according to Bloom (1999), cannot be achieved while the individual is on a constant roller coaster of stimuli and responses.

For these reasons, this research seeks to bring up a new perspective on abusive relationships and the permanence of subjects in these situations, since the lack of studies and scientific publications in Brazil can make approaches to the situation outdated or outdated.

This research is guided by the following guiding question: what is trauma bonding and what are its mechanisms? Thus, the general objective of this work is to analyze trauma bonding in loving relationships, in order to give birth to the neuropsychobiological processes of trauma generated in intimate relationships and investigate the reasons why victims remain in pathological relationships. Specifically, it is intended to: a) Explain what is trauma bonding and how it occurs in an abusive relationship; b) Analyze the reason for a given profile of victims of abuse to remain in these relationships; and c) Explain the functioning of Stockholm Syndrome and posttraumatic stress in victims of abuse in loving relationships as factors that generate trauma bonding.

The methodology used in this study is literature review or literature review. This type of methodology has as its purposes the construction of a contextualization for the problem, as well as the analysis of the possibilities present in the literature consulted for the conception of the theoretical framework of the research.

For this, readings of texts of different genres were made, such as records, reviews and scientific articles related to the subject and which were published in magazines and newspapers in the area. Then, the material collected by the bibliographic survey was organized and analyzed. This analysis contributed to the contextualization, problematization and validation of the theoretical framework used in the research undertaken. 


\section{VIOLENCE AND INTIMATE RELATIONSHIPS}

What drives someone to subject the person they say they love to violence?Reasons may vary, such as substance abuse; previous neurological conditions, which may impact behavior; personality disorders, such as Antisocial Personality Disorder; Borderline Personality Disorder; and Narcissistic Personality Disorder.

As much as the reasons may be diverse, the result is usually the same: the victim suffers the consequences of abuse. Sometimes these partners won't be able to get out of such relationships. The family, friends and those around these victims can tell them to end the relationship and get out of the situation of suffering, appealing to logic; however, the natural functioning of the brain can prevent this from happening.

People who are victims of trauma end up exposing themselves, apparently compulsively, to situations that refer to the original trauma. These behaviors that reactivate trauma are rarely consciously understood as something related to experiences that occurred early in their lives. According to Van Der Kolk (1989), humans are beings who rely on social support to create a sense of personal meaning, security, power, and control. Even our biological maturation is influenced by how bonds have been formed since childhood. Trauma occurs when, both internally and externally, the subject does not have the adequate tools to deal with external threats.

Physical and emotional maturity, as well as innate physiological variations in the process of reacting and perceiving danger, are fundamental in the individual's ability to deal with external threats. The presence of caregivers who provide safety is of paramount importance for the modulation of physiological excitation in children, as well as their absence can make them experience ups and downs in this excitation, which are physiologically aversive and disorganizing. The figure of the caregiver in whom the child can count on to deal with situations for which he is not prepared is fundamental for him to develop biological resources to face lifelong threats (VAN DER KOLK, 1989). 
According to Van Der Kolk (1989), when people who should be the source of physical and emotional protection and nutrition become the source of the danger from which the child should be protected, they tend to readapt and establish an internal meaning of security. Instead of turning against their caregivers and losing hope of obtaining any kind of protection, they blame themselves and become fearful, extremely attached, anxious, and obedient.

The vulnerability of the person victim of trauma at the beginning of life makes them prone to experience trauma, again, in adulthood, since she becomes susceptible to such an event, due to her altered cognitive structure since childhood. For Van der Kolk (1989, p. 391), "people who are exposed to violence and neglect in childhood begin to wait for them as part of life [5]". It is in this context that trauma bonding becomes prone to settling in.

The neurobiological changes that occur in victims of abuse seem to be similar to those of the separation phase of a non-abusive relationship (FISHER et al., 2010). Victims of violence in intimate relationships are different from other victims of violence, because they are close to the aggressor. Therefore, this type of violence is accompanied by a particular emotional dynamic, based on attachment between aggressor victim (SIMONIČ; OSEWSKA, 2019).

When any of us fall in love and connect with someone new, the neurochemistry of the reward system responds, to establish that bond. In circumstances of abuse, the brain has the same attachment that anyone would have for someone they love. However, for victims of abuse, the loved one is not safe and the relationship is not stable (BURKETT; YOUNG, 2012).

What happens neurobiologically in a relationship composed of trauma bonding is not much different from what happens in a healthy relationship. The main difference is that given that the human brain is extremely sensitive to what is happening in the surrounding environment, it releases chemicals in response to the partner's abusive behaviors. If he steps away or behaves aggressively, there will be, in the brain of the 
person with a history of trauma and who is living an abusive relationship, a differentiated reaction, that someone with no history of trauma and who is in a "normal relationship" would not experience. This is also true in brain neurochemistry, with endogenous opioids, dopamine and corticotrophin release factor. (BURKETT; YOUNG, 2012).

\subsection{POST-TRAUMATIC STRESS}

Van der Kolk (1994) explains in his work "The Body Keeps Score: Memory and the evolving psychobiology of post-traumatic stress", which:

O Transtorno de Estresse Pós-Traumático se desenvolve após a exposição a eventos muito angustiantes. O estresse intenso é acompanhado pela liberação de neuro-hormônios endógenos que respondem ao estresse, como cortisol, epinefrina e norepinefrina, vasopressina, ocitocina e opioides endógenos. Esses hormônios ajudam o organismo a mobilizar a energia necessária para lidar com o estresse, desde o aumento da liberação de glicose até o aprimoramento da função imunológica. Em um organismo que funciona bem, o estresse produz respostas hormonais rápidas e pronunciadas. No entanto, o estresse crônico e persistente inibe a eficácia da resposta ao estresse e induz dessensibilização[6]. (VAN DER KOLK, 1994, p. 4).

Posttraumatic stress can be identified through five categories of symptoms, they are: distressing, recurrent and involuntary intrusive memories of the traumatic event; recurring distressing dreams, in which the content and/or feeling of dreams are related to the traumatic event; dissociative reactions (e.g., flashbacks) in which the individual feels or acts as if the traumatic event is occurring again; intense or prolonged psychological distress in the face of exposure to internal or external signs that symbolise or belike some aspect of the traumatic event; intense physiological reactions to internal or external signs that symbolise or belike some aspect of the traumatic event (AMERICAN PSYCHIATRIC ASSOCIATION, 2014).

Such symptoms cause high levels of confusion and distress for survivors, who do not understand how they suddenly got so out of control in their own minds and bodies. Unexpected anger or tears, shortness of breath, increased heart rate, tremors, 
memory loss, concentration problems, insomnia, nightmares and emotional numbness can hijack an identity and a life.

According to Van der Kolk (2001), after the trauma, the human brain undergoes biological changes that it would not have experienced if no trauma had occurred. The impact of these changes is especially exacerbated by three main brain function deregulations:

a) Overstimulated amygdala: After trauma, there is a tendency of the individual to experience emotions as a physical state, rather than verbally encoded experiences.

b) Decreased hippocampus: An increase in the stress hormone cortisol, toxic to the hippocampus, causes it to reduce in size, suggesting loss of cell mass. This makes it less effective at making the sinatic connections required for memory consolidation. This interruption keeps the body and mind stimulated in reactive mode, as none of the elements receives the message that the threat has changed in time past.

c) Lateralization: Van der Kolk (2001) reports, in his study, that there is a tendency for a lateralization to the right hemisphere of the brain, responsible for evaluating the emotional importance of the information received and for the autonomic and hormonal regulation of responses to these stimuli. That is, the right hemisphere of the brain is hyper activated, and, in contrast, the Broca area - part of the left hemisphere responsible for translating personal experiences into verbal communication - has a decrease in oxygen use due to exposure to memories of the traumatic event.

Given the above, it is noted that the memory of the traumatic event, for the brain, is as if the individual is living the situation again, and he can see, hear and feel the sensory elements associated with trauma. There is also physiological impairment when trying to expose the traumatic experience using verbal communication, as well as dissociation of feelings (VAN DER KOLK, 2001). 
Based on the psychobiology of trauma, it is noted that the brain functioning of the individual prevents him from perceiving an abusive relationship as such, since his brain and body are accustomed to stress and neglect, as well as anxiety and fear, which are also caused by such relationships (VAN DER KOLK, 1989).

\subsection{STOCKHOLM SYNDROME}

Graham et al. (1995) developed the Stockholm Syndrome theory, specifically linked to violence practiced in an intimate relationship, based on the psychology and behavior of groups such as cult members, prisoners of concentration camps, civilians held in Chinese Communist prisons, prisoners of war, abused children, incest victims, and prostitutes who had pimps. She argues that four precursors are necessary for the development of Stockholm Syndrome: perceived threat to survival, perception of kindness, isolation and perception of the inability to escape.

Stockholm Syndrome represents a defense mechanism for dealing with these factors, including cognitive and perceptual distortions. Sixty-six items were listed by Graham (behaviors, attitudes and beliefs) as being linked to the Syndrome. Based on these items, Graham developed a 49-item scale to measure Stockholm Syndrome in relationships (GEORGE, 2015).

On the original scale, Graham et al. (1995) found that the items were widely represented by three categories: central Stockholm Syndrome, psychological damage and love addiction.

Central Stockholm Syndrome contained central aspects of Stockholm Syndrome theory and described cognitive distortions and interpersonal traumas. These included rationalizing or minimizing a partner's violent behavior, self-accusation behavior in the face of partner failures or behaviors, and identifying love in the context of fear.

Psychological damage captured depression, low self-esteem and interpersonal difficulties. 
Love dependence was typified by a strong belief that survival itself depended on a partner's affection, extreme idolatry, and the belief that without a partner there would be nothing to live for (GEORGE, 2015).

Romantic love can be considered an addiction, as it demonstrates characteristics of addiction, such as: the intensely focused attention of the subject in a preferred object (in this case, individual), sudden and decontextualized mood swings, intense and uncontrollable desire, obsession with an object/individual, compulsion, distortion of reality, emotional dependence, personality changes, taking high risks to fulfill desires connected to that object/individual, and the loss of self-control in the face of one's own desire. Romantic love tends to be a constructive form of addiction when it is reciprocated, but it can become a destructive addition when rejected (FISHER et al., 2010).

With this dynamic in the cycle of violence, love and rejection, a specific form of connection is created between the two partners, which is mainly based on emotional dynamics and interconnection, by which the victim, despite his rational recognition of violence, feels intimately that he is not able to simply abandon the abusive partner who, in turn, does not change your pattern of behavior. Instead of ending the relationship (and even if he does, returns after a while), the victim ends up strengthening his bond with the aggressor. In this way, the complexity of the abusive relationship deepens and the cycle of violence is repeated (SIMONIČ; OSEWSKA, 2019).

Dutton and Painter $(1981,1993)$ described this type of bond as traumatic bonding, offering a broader description of the victim's and perpetrator's response dynamics, with predictable and unpredictable patterns of violence and responses to it.

\subsection{TRAUMA BONDING}

Trauma bonding is attachment to an abusive relationship and its result is a traumatic affective bond, created in the cycle of violence, which occurs without the individual 
noticing. Victims can ignore the subtle signs of abuse when the relationship is still early and are not aware of the impending emotional abuse; however, as the relationship extends and ties deepen, the pattern of violent and abusive behavior of one part of the relationship tends to become clearer (DUTTON; PAINTER, 1993).

Generally, at the beginning of abusive relationships, episodes of abuse are mild and the pattern of violence is still unclear. In addition, the aggressor says he regrets and apologizes, and the victim accepts them, which reinforces the emotional bond. (DUTTON; PAINTER, 1993). This phase can be just an early short stage of the abusive relationship or last long periods until one enter a new phase of the cycle of violence.

Continuing the relationship of an abusive nature, the trajectory of the cycle of violence follows and the new phase is characterized by the increase in abuse. The victim may come to believe that something is wrong with her and that she is responsible for changing something in herself, which would prevent violence. Cognitive reactions are triggered such as self-accusation, guilt, introjection, transfer of responsibility for abuse to itself, and not to the aggressor, configuring a representation of events and even a distorted self-representation. This distorted notion can temporarily serve as a social justification for dealing with abuse and a rational explanation for it, however, by leading the victim to continue in the relationship, such a posture contributes to the victim's inability to definitively end the cycle of violence (DUTTON; PAINTER, 1981).

Two characteristics of violent relationships contribute to the formation of trauma bonding in the intimate relationship: the imbalance of power and the eventual intermitience of violence or, in other words, the cycle of violence interspersed with the phase of the "honeymoon". The imbalance of power occurs when an individual, who plays a subordinate role, develops a low self-esteem, reduces their self-efficacy and becomes more dependent on the violent partner, that is, the person in a dominant position (DUTTON; PAINTER, 1993). 
A patriarchal social structure, characterized by stereotyped gender roles, can also contribute to this. If the partner in the dominant position is abusive, the victim ends up being emotionally and existentially imprisoned. This creates a feeling of helplesss in the subject and strengthens attachment, because the victim, who sees himself as weak, internalizes the negative perception of the aggressor about him, making him even more dependent and powerless, which creates a strong affective bond with the person who is seen as stronger (SIMONIČ; OSEWSKA, 2019).

The dependence of the person perceived as more fragile hides, in fact, the dependence and impotence of the aggressor, because it also depends on the victim. For this reason, the aggressor temporarily interrupts violent behavior, for fear of having crossed the line and the victim leaving him. The anxiety that arises in the aggressor leads to a behavior of appeasement, with the interruption of physical and verbal violence, but usually still preserving psychological manipulation. In this way, the aggressor tries to keep the victim at his side, when faced with the possibility of being abandoned. Using the theory of attachment, which examines intimate relationships between adults as attachment relationships, the anxiety that accompanies the possibility of losing the person to whom it is attached is the basis of such a pathological relationship (DUTTON; WHITE, 2012).

According to Johnson (2008), attachment needs in a relationship are healthy, but in the case of abusive relationships, the problem arises when such needs are created in a context of uncertainty, generated by conflict. Relationship security helps people regulate their emotions, process information, and communicate clearly. Those who have healthy ties can openly admit their insecurity and turn to others for support, receiving reception and an adequate response to the situation.

Violence, however, is a dysfunctional way of staying close to the person to whom it clings when the need to bond is awakened. The victim becomes anxious, which makes it difficult for her to leave the relationship, as well as her aggressor, who wishes to keep control over the victim, so that she does not abandon him (FINKEL; SLOTTER, 2007). 
In this case, a paradox occurs: violence increases the anguish of the victim, who wishes to escape, while raising the need for bonds that could regulate such anguish, which she seeks in people she considers stronger than her. Thus, the aggressor becomes a source of fear and, at the same time, protection. The traumatic bond is, therefore, a source of trauma, as well as a bond that provides security (SIMONIČ; OSEWSKA, 2019).

Similar dynamics are present in Stockholm Syndrome, in which the victim develops a strong emotional bond with the aggressor. This syndrome, based on cognitive and perception distortions and attachment, is, in this context, a defense mechanism to deal with such factors.

Trauma bonding is formed and maintained, too, due to a particular activity at the organic level of both partners in an abusive relationship, characterized by dysregulation in the secretion of dopamine, endogenous opioids, corticotrophine and oxytocin, hormones that contribute to "addiction to trauma". (BURKETT; YOUNG, 2012).

Oxytocin provokes a very powerful neurological response, which promotes the creation of bonds and the building of trust with the partner. Attachment and the connection between the victim and the aggressor are the same as those of all other relationships: reinforced by excess oxytocin.

Dopamine stimulates desire, search and seed for the other.

Endogenous opioids are associated with regulating the proportion of pleasure and pain, abstinence and dependence.

The release of corticotrophine is associated with the perception of stressful situations and reactions to stress. In case of violence, intense neurochemical processes are usually activated. The problem is that such neurobiological processes, which activate attachment to relieve stress, occur in toxic and harmful relationships, which are also a source of stress, which makes these processes deregulated and causes the victim 
to become increasingly dependent on the aggressor, causing a vicious circle, such as the cycle of domestic violence (FISHER et al., 2010).

\section{FINAL CONSIDERATIONS}

In view of the above, the central questioning made at the beginning of this research on the definition of trauma bonding and what its mechanisms are contemplated in a way that it is possible to infer that several emotional and neuropsychobiological factors are presented as the cause for trauma bonding to be established within a relationship, and understanding these variables becomes fundamental, both for the therapeutic elaboration of the traumatic bond, as for the process of treatment of victims and change of their dissonaning and harmful patterns.

Moreover, it is known that increased vulnerability to trauma bonding formation in a loving relationship is linked to individuals with a history of abuse and violence in childhood.

Such early life experiences interrupt the natural process of creating healthy bonds and alter the brain structure of the subject, causing greater susceptibility to engage in an abusive relationship, both by internal and hormonal factors and by external factors, which give him a lower device to deal with the perception of danger and the formation of positive bonds, making you feel inability to leave the relationship.

Interpersonal regimens in adult individuals with a history of abuse tend to be negative and untestable in different relationships. These schemes can motivate behavior that increases the likelihood of revictimization.

Thus, it is understood that the general objective proposed: to analyze trauma bonding in loving relationships, in order to give birth to the neuropsychobiological processes of trauma generated in intimate relationships and to investigate the reasons why victims remain in pathological relationships was clearly contemplated. 
Moreover, in view of all the theoretical compound that was made, it is believed that this study has significant importance in bringing up some aspects related to trauma bonding, without, however, exhausting the theme. Thus, it is intended that this article be the basis for further studies to be developed on this institute contributing positively to the dissemination of knowledge.

\section{REFERENCES}

AMERICAN PSYCHIATRIC ASSOCIATION - APA. Manual diagnóstico e estatístico de transtornos mentais: DSM-V. Porto Alegre: Artmed, 2014.

BLOOM, Sandra L. Trauma theory abbreviated. [s.l.: s.n.], 1999. Disponível em: https://strengthcounselling.ca/wp-content/uploads/2018/05/trauma-theoryabbreviated.pdf. Acesso em: 15 abr. 2021.

BURKETT, James P.; YOUNG, Larry J. The behavioral, anatomical and pharmacological parallels between social attachment, love and addiction. Psychopharmacology, v. 224, n. 1, p. 1-26, 2012. Disponível em: https://www.ncbi.nlm.nih.gov/pmc/articles/PMC3469771/. Acesso em: 15 dez. 2020.

CARNES, Patrick J. Betrayal Bond: Breaking Free of Exploitive Relationships. [s.l.]: Health Communications, Incorporated, 2019.

DEYOUNG, M.; LOWRY, JA. Traumatic bonding: clinical implications in incest. Child Welfare, 1992 Mar-Apr;71(2):165-175.

DUTTON, Donald; PAINTER, S. L.Traumatic bonding: The development of emotional attachments in battered women and other relationships of intermittent abuse. Victimology, 6, 139-155, 1981.

DUTTON, Donald G.; PAINTER, Susan. Emotional Attachments in Abusive Relationships: A Test of Traumatic Bonding Theory. Violence and Victims. v. 8, n. 2, p. 105-120, 1993. 
DUTTON, Donald G.; WHITE, Katherine R. Attachment insecurity and intimate partner violence. Aggression and Violent Behavior, v. 17, n. 5, p. 475-481, 2012.

FESTINGER, Leon. Cognitive Dissonance. Scientific American, v. 207, n. 4, p. 93 106, 1962.

FISHER, Helen E.; et al. Reward, Addiction, and Emotion Regulation Systems Associated With Rejection in Love. Journal of Neurophysiology, v. 104, n. 1, p. 5160, 2010.

GEORGE, Vera. Traumatic Bonding and Intimate Partner Violence. [s.l.: s.n.], 2015. Disponível em: https://core.ac.uk/download/pdf/41339659.pdf. Acesso em: 23 Nov. 2020.

GRAHAM, D. L.; RAWLINGS, E. I.; IHMS, K.; LATIMER, D.; FOLIANO, J.; THOMPSON, A.; SUTTMAN, K.; FARRINGTON, M.; HACKER, R. A scale for identifying "Stockholm syndrome" reactions in young dating women: factor structure, reliability, and validity. Violence Vict, 1995 Spring;10(1):3-22. PMID: 8555117.

JOHNSON, M. P. A typology of domestic violence: intimate terrorism, violent resistance, and situational couple violence. Boston: Northeastern University Press, 2008.

MARTín, A. G. As sequelas psicológicas da tortura. Psicologia: Ciência e Profissão [online]. 2005, v. 25, n.3, pp. 434-449. Disponível em: <https://doi.org/10.1590/S1414-98932005000300008>. Acesso em: 22 Ago 2021.

SIMONIČ, Barbara; OSEWSKA, Elzbieta. Traumatic bonding in intimate partner violence: A Relational Family Therapy approach. Family Forum., v. 9, n. 10, 2019. 25167/FF/1092, p. 71-90, 2020.

VAN DER KOLK, Bessel A. The Compulsion to Repeat the Trauma. Psychiatric Clinics of North America, v. 12, n. 2, p. 389-411, 1989. 
VAN DER KOLK, B. A. The Body Keeps the Score: Memory and the Evolving Psychobiology of Posttraumatic Stress. Harvard Review of Psychiatry, v. 1, n. 5, p. 253-265, jan. 1994.

VAN DER KOLK, Bessel A.; SAPORTA, Jose. The biological response to psychic trauma: Mechanisms and treatment of intrusion and numbing. Anxiety Research, v. 4, n. 3, p. 199-212, 1991.

VAN DER KOLK, B. A. The psychobiology and psychopharmacology of PTSD. Human Psychopharmacology: Clinical and Experimental, v. 16, n. S1, p. S49-S64, jan. 2001.

\section{APPENDIX - REFERENCE FOOTNOTE}

3. Free translation of the authors.

4. Free translation of the authors.

5. Free translation of the authors.

6. Free translation of the authors.

Submitted: October, 2021.

Approved: November, 2021. 